\title{
Development of Braille Number Card As Learning Media on Integer Materials for Blind Students
}

\author{
Shendy S Igirisa ${ }^{1, a^{*}}$, Yusuf Fuad ${ }^{1, b}$, and Sumarno Ismail ${ }^{2}$ \\ 1Department of Mathematics Education, Universitas Negeri Surabaya, Surabaya, East Java, Indonesia \\ 2Department of Mathematics, Universitas Negeri Gorontalo, Gorontalo, Indonesia \\ a shendyiigirisa16070785021@mhs.unesa.ac.id; b yusuffuad@unesa.ac.id; c sumarno.ismail.si@gmail.com \\ ${ }^{*}$ Corresponding Author \\ Whatsapp Number [081917183523]
}

How to Cite: Igirisa, S., S., Fuad, Y., \& Ismail, S. (2018). Development of Braille Number Card As Learning Media On Integer Materials for Blind Students. International Journal for Educational and Vocational Studies, 1(4), 268-272

\section{ARTICLE HISTORY}

Received: 18 June 2019

Revised: 20 July2019

Accepted: 5 August 2019

\section{KEYWORDS}

\section{Braille Number Card;}

Learning Media;

Integer Materials;

Blind Students

\begin{abstract}
Losing vision for blind students makes them difficult to access education. Thus, blind students need special tools like interesting and applicable learning media, teaching methods, and techniques for them. This study was developmental research that aimed to describe the result of instructional media development of braille number card to improve blind students' understanding on integer number and describe their understanding after using braille number card as learning media at special needs elementary school. The subjects of this study consisted of three students with low vision, partially sighted students, and blind students. The research model used was ADDIE development model (analysis, design, development, implementation, and evaluation). Data were collected using test and questionnaire to know their understanding of braille number card as learning media on integer numbers. The result showed that blind students responded positively with an average score of $83 \%$ and $66.7 \%$ of their learning test. Therefore, It can be concluded that braille number card as instructional media can be used in teaching and learning activity to improve blind students' understanding.
\end{abstract}

This is an open access article under the CC-BY-SA license.

\section{INTRODUCTION}

Mathematics learning is the process of providing students with learning experiences through a series of planned activities so they can master mathematics competence. NCTM (2000: 64) Mathematics innovative learning requires an understanding of what students know and need to learn and challenges and supports them to learn it well.

Special needs School is an institution that accommodates students with special needs. One of them is students with low vision, commonly called students with visual impairment. The International Classification of Functioning (2007) defines disability the outcome of the interaction between a person with impairment and the environmental and attitudinal barriers they may face. Especially visually impaired term that includes, blind and partially sighted. Blind people can be understood as a condition in which a person is unable to see things clearly. Efendi (2008: 18) state that blind student is defined as $\mathrm{s}$ person whose sense of vision does not function as means to recieve daily information like an normal person. Losing vision makes blind students difficult to access education.
Thus, blind students need special tools like an interesting and applicable learning media, teaching methods and techniques for them. While according to Ormrod (2008: 252), blind students are categorized info two categories: students with total blindness and students with low vision

Based on interview in Januari 2018 with some mathematic teachers at SLB in Gorontalo, such as SLB Negeri Kota Gorontalo and SLB Negeri Kabupaten Bon Bolango, resulted information thet blind students in elementary school are challenged at addition and subtraction of integers. Integers are an abstract material. The abstraction can be seen from the negative integers that are rarely used in everyday life so that students often make mistakes in determining the integer multiplication and division. Kristiono (2008: 3) besides, addition, subtraction, multiplication and division are foundation of mathematics. Understanding the basic concepts of integers, especially integer multiplication and division supports mastery of further concepts, because many materials are related with concept of integer 
multiplication and division. Sudijono (2009: 112) Understanding is a higher level of thinking than knowing and memorization. Therefore, learning media is needed to improve blind students' understanding on integer operation. Fredy \& Sunaryo (2013: 163) state that "Addition and subtraction are important parts of life and you don't usually go through a day without needing to add or subtract something. addition and subtraction are also the building blocks for more advanced math".

Widjaya (2014: 21) state that that media used by visually impaired students are reading boards (Regular), Reglete and Stylus (pen) manual stationery, Braille typewriter (Perkins Braille), cassette. Learning media applied to blind students in some special needs schools includes: braille reading aids (letterhead and optacon board); numerical aids (Cubaritma, Abacus / Abacus, Speech calculators), as well as audio aids such as taperecorders.

Blind students cannot use their sense of sight, but they can still use other senses, like the sense of hearing and touch. Therefore the use of learning media that can utilize the senses of hearing and touch is a special learning media for blind students, which aims to help students in counting. Azmi (2016: 62) states that education is the basis for the process of forming the nation's next generation.

Learning media used by writer was braille number card that helped students to solve the calculation problems, especially integer multiplication and division by optimizing their sense of touch.

The purpose of this study was to describe the development of braille number card as learning media on integer numbers for blind student learning and to describe their understanding of integer material after using braille number card.

\section{MATERIALS AND METHODS}

This study was development research using ADDIE development model consisting of Analyze, Design, Development, Implementation and Evaluation. Subjects of this study were 5 students with special needs at SDLB type A for trial test while 3 student with special needs at SDLB type A were treated using this media. Subject were selected by providing an initial test on integer materials of blind students at SDLB-A to obtain equal ability.

Gustafson and Branch (2002: 15) said that in the instroctional develompent of learning or instructional development, the main core of the ADDIE process is the analysis of the background and needs of students, the design of a set of specifications for an effective, efficient and relevant learning environment, development of all learning materials and arranging the material, implementing the instructions produced, and formative and summative evaluations both the results of development. Mulyaningsih (2014:201) the following explained these five stages of development adapted to this study.

Tabel 1. ADDIE developmental model stages

\begin{tabular}{cl}
\hline $\begin{array}{c}\text { Stages of } \\
\text { development }\end{array}$ & \multicolumn{1}{c}{ Activity } \\
\hline Analysis & $\begin{array}{l}\text { Initial planning. } \\
\text { So some analysis to procure new media products. } \\
\\
\text { Conduct needs analyis, student analysis and curriculum } \\
\text { analysis. } \\
\text { So that the products procuced can meet axisting needs, } \\
\text { according to the characteristics of students and contained in } \\
\text { the learning curriculum in SLB Kabupaten Bone Bolango }\end{array}$ \\
\hline Design & $\begin{array}{l}\text { Design the materal to be used. } \\
\text { Learning media products and intructions for use }\end{array}$ \\
& $\begin{array}{l}\text { Arrange the learning implementation plan used. } \\
\text { Design instruments for media enhancements }\end{array}$ \\
\hline Development & $\begin{array}{l}\text { Develop product device with media validation by validator. } \\
\text { Repaired according to the advice given } \\
\text { Tested at SLB Kota Gorontalo }\end{array}$ \\
\hline & $\begin{array}{l}\text { Implementation of Braille number card media for blind } \\
\text { students. }\end{array}$ \\
& $\begin{array}{l}\text { Take data about the practicality of number card learning } \\
\text { media through the media evaluation sheet by the teacher }\end{array}$ \\
& $\begin{array}{l}\text { Take data on the effectiveness of numerical card learning } \\
\text { media through student response questionnaire sheets and } \\
\text { learning outcomes tests }\end{array}$ \\
\hline Evaluation & $\begin{array}{l}\text { Looking back on the impact of learning by looking at the data } \\
\text { obtained at the implementation stage. Such as media } \\
\text { evaluation sheets by giri, student response questionnaire } \\
\text { sheets and tests of student learning comprehension.. }\end{array}$ \\
\hline &
\end{tabular}

\section{RESULTS AND DISCUSSIONS}

This research produced a new product of Braille Numbers Card as learning media for students with visual impairment by optimizing their senses of touch. The subjects of this study were 3 blind students with different levels of blindness (low vision, partial blind and totally blind).

\subsection{Analysis Stage}

Needs analysis was conducted using interviews to teachers at SLB Bone Bolango to know the problems related to the process of learning mathematics. The obtained information was: the lack of learning media was found because of the limitations of media for students with visual impairment. Learning media used was still a manual media and objects around class. Thus, It was necessary to develop media that could help students learn about integer operations. Furthermore, the student analysis such as characteristics and the level of student blindness found were low vision, partial sighted and totally blind students, and analysed the level of students' interest in using learning media.

Curriculum analysis was also done by focusing on the basic competencies for students, such as multiplication and division of positive integer numbers, multiplication and division of negative integers and multiplication and division of mixed integers. 


\subsection{Design Stage}

In this stage, the contents planning, product design, learning implementation design for students on multiplication and division of integers, the instrument framework and test of learning outcomes were conducted.

\subsection{Development Stage}

This media was modified from numbers Card used for normal students with different colors card. While, For blind students, the number cards used are the triangular form representing units, the quadrilateral representing the tens and circles representing hundreds. On two sides of number card were positive side with fine texture and negative side with coarse texture. the number Card is used as a learning media for blind students on multiplication and distribution of integers.

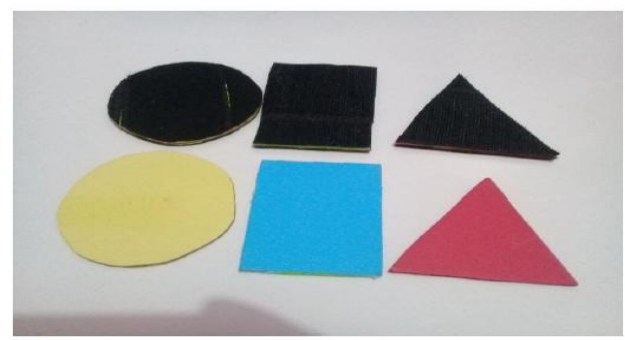

Figure 1. The Example Of Modified Braille Number Card

At the development stages, the media trial was developed based on results of evaluation analysis by teachers follows.

Tabel 2. Result of Evaluatin Analysis

\begin{tabular}{|c|c|c|c|}
\hline No & Scoring indicator & Item & Score \\
\hline 1 & Safe & 1,2 & 2 \\
\hline 2 & Easy & 2,4 & 2 \\
\hline 3 & Interesting & 5 & 1 \\
\hline 4 & Trigering to move & 6,7 & 2 \\
\hline 5 & Appropriate with the needs & 8,9 & 1 \\
\hline 6 & Appropriate with the goal & $10,11,12$ & 2 \\
\hline 7 & Difficully to break & 13 & 1 \\
\hline 8 & Appropriate to environment & 14 & 1 \\
\hline Total & & 14 & 12 \\
\hline
\end{tabular}

The Feasibility percentage was $85.71 \%$. meaning that the media was categorized as very feasible / effective and the product could be used without scale.

\subsection{Implementation Stage}

The results showed the quality of media referring to validation results by the validator was very valid. Media practicability referring to media evaluation by the teacher was very practical with the percentage of $92.86 \%$.

Table 3. Result Of Evaluation Validity

\begin{tabular}{|c|c|c|c|}
\hline No & Scoring indicator & Item & Score \\
\hline 1 & Safe & 1,2 & 1 \\
\hline 2 & Easy & 2,4 & 2 \\
\hline 3 & Interesting & 5 & 1 \\
\hline 4 & Trigering to move & 6,7 & 2 \\
\hline 5 & Appropriate with the needs & 8,9 & 1 \\
\hline 6 & Appropriate with the goal & $10,11,12$ & 3 \\
\hline 7 & Difficully to break & 13 & 1 \\
\hline \multirow[t]{2}{*}{8} & Appropriate to environment & 14 & 1 \\
\hline & Total & 14 & 13 \\
\hline
\end{tabular}

In this study, the modified braile number card as learning media was conducted in 5 meetings by teacher for blind students.

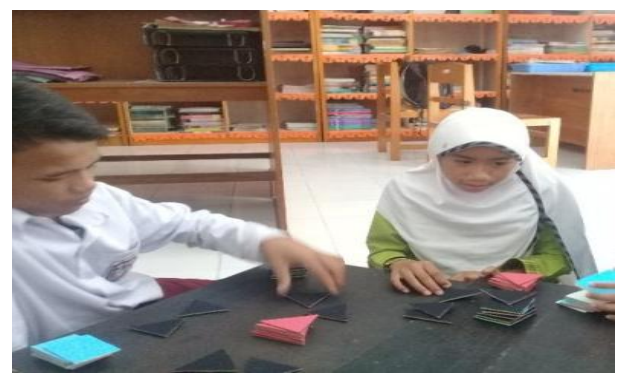

Figure 2. Example of Braille number Card Media Usage

\subsection{Evaluation Stage}

Questionnaire given to students after the implementation of developed media. This questionnaire was aimed to find out the role of learning media for students. The average percentage of questionaire given to studens was $83 \%$, meaning that media was categorized as possitive.

Table 4. Results of student response questionnaire

\begin{tabular}{cccccccccccc}
\hline & \multicolumn{10}{c}{ Statement } & Perce \\
Respondents & 1 & 2 & 3 & 4 & 5 & 6 & 7 & 8 & 9 & 10 & \\
\hline Rahmat & 1 & 1 & 1 & 1 & 0 & 1 & 1 & 1 & 0 & 1 & $80 \%$ \\
\hline Mey & 1 & 1 & 1 & 1 & 1 & 1 & 1 & 0 & 1 & 1 & $90 \%$ \\
\hline Melin & 1 & 1 & 1 & 1 & 1 & 0 & 1 & 0 & 1 & 1 & $80 \%$ \\
\hline & \multicolumn{1}{c}{ Average Percentage } & & & $83 \%$
\end{tabular}

The test for students' learning outcomes was conducted to know how far the role of developed braille number card media on students' knowledge of integer operation. It was done by giving them some problem about multiplication 
material and integer division. The questions had been validated before. Test results showed that $66.7 \%$ of students achieved mastery of materials.

Table 5. Results of data analysis of student learning outcomes test

\begin{tabular}{|c|c|c|c|c|c|c|c|c|c|c|}
\hline \multirow{2}{*}{$\begin{array}{l}N \\
0\end{array}$} & \multirow[t]{2}{*}{$\begin{array}{l}\text { Respon } \\
\text { dents }\end{array}$} & \multicolumn{6}{|c|}{ Score of question indicator } & \multirow[t]{2}{*}{ Total } & \multirow{2}{*}{$\begin{array}{l}\text { Total } \\
\text { scor } \\
\text { e }\end{array}$} & \multirow[t]{2}{*}{ remark } \\
\hline & & $\begin{array}{c}1 \\
(20)\end{array}$ & $\begin{array}{c}2 \\
(26)\end{array}$ & $\begin{array}{c}3 \\
(11)\end{array}$ & $\begin{array}{c}4 \\
(20)\end{array}$ & $\begin{array}{c}5 \\
(12)\end{array}$ & $\begin{array}{c}6 \\
(16)\end{array}$ & & & \\
\hline 1 & Rahmat & 0 & 0 & 0 & 0 & 0 & 0 & 0 & 0 & $\begin{array}{l}\text { Not } \\
\text { completed }\end{array}$ \\
\hline 2 & Mey & 16 & 20 & 11 & 10 & 12 & 0 & 69 & 75 & Complted \\
\hline 3 & Melin & 18 & 16 & 9 & 10 & 12 & 16 & 81 & 85 & completed \\
\hline
\end{tabular}

\subsection{Discussion}

Hamalik (2001:80) state that improvement of students' understanding can be seen when they can explain and elaborate the material by using their own language in detail. In this study, Blind Students with three different levels of blindness can complete the test of learning outcomes where their score was above the determined mastery standard.

Kohanova (2013) state that "The most frequent mathematical problems of blind pupils are as follows: (1) generalizing - finding the similarities in different activities in everyday life; (2) translating activities and action into mathematical language; (3) lacking flexibility in problem solving and in calculations; and translating and transferring three-dimensional objects into two-dimensional iconic forms.

The subjects are special because they had impaired vision condition. According to Widjaya (2014: 92) blind students use media that can be reached by sense of hearing and touch. In this study, the use of braille number card optimized the use of students' sensory senses. Braille number cards are considered practical and interesting to be used by students with visual impairment at SLB type A.

\section{CONCLUSION}

The developed Braille number cards as Learning media have been considered valid and practical so they can be used as an alternative learning media and can be used as an additional media for students with visual impairment. The results of student learning tests provide information that the developed media can be used to improve students' learning comprehension

This study was not completed without the support of officers at SLB in Bonebolago district, Gorontalo Province so the writers are deeply grateful to the principal and the fourth grade math teacher who has helped in research activities. The opinions expressed here do not necessarily reflect the position, policy, or endorsement of the supporting agency.

\section{REFERENCES}

Asshiddiqie, Jimly \& Hafid. (2015). Hak Asasi Manusia dalam Konstitusi Indonesia. Jakarta: Kencana ISBN 978-602-1186-65-7

Azmi, Nurul. (2017). Development of an Android-based Learning Media Application for Visually Impaired Students. Indonesian Journal of Informatics Education. ISSN : 2549-0389. Vol.1 Issue. 1.

Crawford, M. L. (2001). Teaching contextually: research, rationale, and techniques for improving student motivation and achievement in mathematics and science. Texas: CCI Publishing, Inc

Depdiknas. (2003). Kurikulum 2004 Standar Kompetensi Sekolah Dasar. Jakarta : Depdiknas.

Efendi, Mohammad. (2008). Pengantar Psikopedagogik Siswa Berkelainan. Jakarta: PT Bumi Aksara

Fredy \& Soenarto. (2013). Developing Math Multimedia on Integer Materials At Grade 4 In SDN Of Lempuyangan 1 Yogyakarta. Yogyakarta: Jurnal Prima Edukasia Vol. 1, No. 2

Gustafson \& Branch, (2002). Survey of Instructional Development Models. Fourth Edition. New York: ERIC Clearinghouse on Information and Technology.

Hamalik, Oemar. (2001). Proses Belajar Mengajar. Jakarta : Bumi Aksara.

ICEVI (International Council Education of People with Visual Impairment), (2005). Mathematics Made Easy for Children with Visual Impairment. Philadelphia: Towers Press.

International Classification of functioning, disability, and healt. (2007). Chuldren \& Youth Version. WHO

Kohanova, Iveta. (2013). Technologies And Tools In Teaching Mathematics To Visually Impaired Students. Slovakia: Comenius University Bratislava

Kristiono. Heru. (2008). Mahir Perkalian dan Pembagian Bilangan Dasar melalui Media Permainan Kartu. Jurnal Pendidikan Penabur. No. 1 Tahun 7

Mulyatiningsih, Endang. (2014). Metode Penelitian Terapan Bidang Pendidikan. Bandung: Alfabeta

Nabilah, Hullatun. (2015). Proses Berfikir Siswa Tunanetra dalam Memecahkan Masalah Materi Geometri. Jurnal Pendidikan Matematika STKIP PGRI Sidoarjo ISSN: 2337-8166 Vol. 1 No. 1.

Nurajab, D. D. (2016). Keefektifan Permainan Domino Braille Terhadap Kemampuan Penjumlahan dan 
Pengurangan Pada Mata Pelajaran Matematika Siswa Tunanetra Kelas 1 di SLB A Yaketunis Yogyakarta. Jurnal Universitas Negeri Yogyakarta Vol. 1. No. 1

NCTM. (2000). Principle and Standard for School Mathematics. Reston: The National Council of Teacher Mathematics.

Ormrod, J. (2008). Psikologi Pendidikan Membantu Siswa Tumbuh dan Berkembang. Jakarta: Erlangga

Purwoto. (2003). Strategi Pembelajaran Matematika. Surakarta : Sebelas Maret University Press.

Ratumanan, T. G. (2004). Belajar dan Pembelajaran. Surabaya: Unesa University Press.

Sudijono, Anas. (2009). Pengantar Evaluasi Pendidikan. Jakarta: Rajawali

Widjaya, Ardhi. (2014). Seluk-Belum Tunanetra \& Strategi Pembelajarannya. Jogjakarta: Javalitera

Wongkia. Wararat. (2012). i-Math: Automatic math reader for Thai Blind and Visually Impaired Students. Thailand: Department of Mathematics Faculty of Science. Mahidol University. 